\title{
Millennial/submillennial-scale sea-level fluctuations in western Mediterranean during the second highstand of MIS 5e
}

\author{
C.J. Dabrio ${ }^{\mathrm{a}, *}$, C. Zazo ${ }^{\mathrm{b}}$, A. Cabero ${ }^{\mathrm{C}}$, J.L. Goy ${ }^{\mathrm{d}}$, T. Bardaji ${ }^{\mathrm{e}}$, C. Hillaire-Marcel ${ }^{\mathrm{f}}$, J.A. González-Delgado ${ }^{\mathrm{d}}$, \\ J. Lario ${ }^{\text {c }}$, P.G. Silva ${ }^{\mathrm{d}}$, F. Borja ${ }^{\mathrm{g}}$, A.M. García-Blázquez ${ }^{\mathrm{d}}$

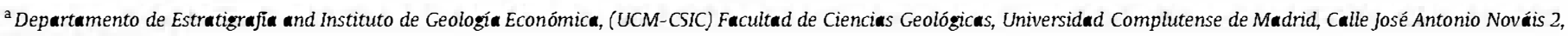 \\ 28040 Madrid, Spain \\ ${ }^{\mathrm{b}}$ Departamento de Geología, Museo Nacional de Ciencias Naturales, CSIC, Madrid, Spain \\ ${ }^{c}$ Facultad de Ciencias, UNED Madrid, Spain \\ ${ }^{\mathrm{d}}$ Departamento de Geología, Universidad de Salamanca, Spain \\ e Departamento de Geología, Universidad de Alcalá Madrid, Spain \\ i GEOTOP-UQAM, Canada \\ ${ }^{g}$ Áre de Geografia Fisica, \\ Facultad de Humanidades
}

\section{Introduction}

It is a general opinion that the duration of the Last Interglacial, Marine Isotope Stage (MIS) Se, was around 17-18 ka, between 133 and $\sim 116 \mathrm{ka}$, and that global sea level rose above present elevations (Zhu et al., 1993; Szabo et al., 1994; Hearty and Kindler, 1995; Neumann and Hearty, 1996; Hillaire-Marcel et al., 1996; Blanchon and Eisenhauer, 2001; Shackleton et al., 2002). However, the estimates of sea-level position deduced from records of sea level on different coastlines could very well differ owing to tectonics, glaciohydro-isostatic effects, rate of reef growth, and accuracy of dating methods. U-Th dating of fossil corals is currently considered the best direct method to obtain benchmarks aimed to reconstruct the history of sea level. Despite significant improvement in analytical techniques, the age artifacts imposed by open-system effects even in corals could not be overcome (Stein et al., 1993; Andersen et al., 2009). Concerning U-series ages based on mollusc shells, opensystem behaviour also introduces large uncertainty (Szabo and Rosholt, 1969; Kaufman et al., 1971; Bernat et al., 1985, O'Leary et al., 2008). Thus, in a worldwide revision of sea level during the 
Last Interglacial-MIS Se (Hearty et al., 2007), U-Th ages proved useful to confirm the age of deposits but, unfortunately it was possible to corroborate the highstand subdivisions using radiometric ages only in two cases.

Significant sea-level fluctuations during MIS 5e have been reported in many sites from geomorphological and morphostratigraphic evidence (Plaziat et al., 1998; Schellmann et al., 2004; Schellmann and Radtke, 2004; Dumas et al., 2006; Rohling et al., 2008; Accordi et al., 2010). A global MIS 5e sea-level curve has been presented by Hearty et al. (2007), with assumed average duration between $130 \pm 2$ and $119 \pm 2 \mathrm{ka}$. They included several fluctuations: a post-glacial rise before $130 \mathrm{ka}$, a period of stability at +2 to $+3 \mathrm{~m}(\sim 130-125 \mathrm{ka})$ above present sea level (a.s.l.)followed by a minor regression and sea-level fall, and a new rise to +3 to $+4 \mathrm{~m}$ a.s.l. $(\sim 124-122 \mathrm{ka})$. The end of MIS Se $(\sim 120-118 \mathrm{ka})$ is characterized by a series of rapid sea-level changes between +6 and $+9 \mathrm{~m}$ a.s.l., with an apparent fall of sea level at $119 \mathrm{ka}$.

In Bahamas, White et al. (1998) differentiated two phases (132-125 ka and 124-119 ka) of coral reef growth, separated by a rapid fall of sea level, near the present, during the sustained MIS se highstand. The transgression/regression cycle occurred in $1.1-1.5 \mathrm{ka}$ with a total change of sea level of $10 \mathrm{~m}$ during the fall and subsequent rise.

Rapid sea-level changes during the early part of MIS Se have been reported from the Gulf of Corinth (Greece). There, the early MIS 5e highstand ( $\sim 137$ to $\sim 135 \mathrm{ka}$ ) was punctuated by two significant $(>10 \mathrm{~m})$ eustatic sea-level falls, which probably occurred in less than 1000 yr (Andrews et al., 2007).

The absence or scarcity of fossil corals in Spanish coasts makes it necessary to use U-series measurements, amino-acid racemization (AAR), and other techniques. Dating on mollusk shells recovered from marine deposits, with very limited assistance from corals has been used (e.g.: Hillaire-Marcel et al., 1986, 1996; Hearty, 1986, 1987; Causse et al., 1993; Zazo et al., 1999, 2002). Numerous studies have been devoted to Mallorca Island (Balearic Islands) aimed to investigating sea-level changes during MIS Se. U-series measurements on mollusk shells recovered from three morphosedimentary units produced two groups of ages: $\sim 135 \mathrm{ka}$ for the older unit and $\sim 117 \mathrm{ka}$ for the other two, more recent ones (Hillaire-Marcel et al., 1996). Field investigation suggested that the three marine units represent three different highstands (Goy et al., 1997). U-series ages of phreatic overgrowths on speleothems developed in eastern Mallorca littoral caves suggested two sea-level highstands ( 135-130 ka and 120-118 ka) separated by a lowstand at a maximum depth of $16.5 \mathrm{~m}$ around $125 \mathrm{ka}$ (Ginés et al., 2005; Tuccimei et al., 2006). Because of the large amplitude of sea level changes ( $19 \mathrm{~m})$, rapid ice melting and accumulation during discrete intervals of time have been suggested.

Hearty (1987) dated Last Interglacial deposits in Mallorca Island my means of AAR and $U-T h$ measurements. Calibration of aminozone $\mathrm{E}$ (MIS Se) relays on a $129 \pm 7 \mathrm{ka} U$-series coral age on Cladocora caespitosa from Palma Bay. Three minor oscillations during MIS Se were proposed in this synthesized sea-level curve of Mallorca.

A synthesis of the Pleistocene marine terraces of the Spanish coast based on geomorphological mapping, morphosedimentary analysis, and faunal content, and supported by U-series dating (Zazo et al., 2003) suggested the occurrence of up to three highstands during MIS 5e, between $\sim 135$ and $\sim 117 \mathrm{ka}$. The three bear the "Senegalese" warm fauna (Strombus bubonius, Cardita senegalensis, Conus testudinarius, etc.). The oldest highstand was recorded in some of the east-facing coastal sectors of the Iberian Peninsula as prograding oolitic beach-coastal dune systems. The second is biosiliciclastic and includes the most complete sedimentary and paleontological records, with a high number and variety of Senegalese species. The third, younger, highstand is represented by poorlysorted boulders imbedded in a reddish matrix, and suggest deposition during a short period characterized by increase in both storminess and rainfall. Bardaji et al. (2009) proposed changes in the pattern of prevailing winds as one of the causes of the facies change: the initially prevailing eastern winds turned to strong northerly winds by the end of MIS Se, with increased storminess and runoff.

These three highstands have been recognized in the general sealevel curve of the Mediterranean basin proposed by Hearty et al. (2007), based on data from Italy, Spain and Tunisia. These positive fluctuations were interrupted by minor falls of sea level with amplitudes $\leq 3 \mathrm{~m}$. The second highstand represents the highest rise of sea level and was the longest, with duration around $10 \mathrm{ka}$.

The aim of this paper is to analyze the repeated, small-scale changes of sea level recorded in a prograding barrier spit that grew during MIS Se at La Marina-El Pinet site (Alicante, Fig. 1). The study is a continuation of previous investigations in the area (Zazo et al., 2003; Goy et al., 2006) that were supported by geomorphologic mapping, facies analysis, and U-series measurements on mollusk shells and corals. However, in this case, we focus on the bio-siliciclastic facies of the second highstand of MIS 5e that is the best exposed. We paid particular attention to the geometry and 3D architecture of beach facies, and petrographic analyses to investigate small-scaled fluctuations of sea level inside this highstand, and its possible local/regional climatic meaning.

\section{Geological setting}

La Marina-El Pinet area is located in the Eastern Betic Ranges, where major tectonic activity took place between the Lower and Middle Pleistocene (Goy and Zazo, 1989; Goy et al., 1989). This neotectonic event produced folds and flexures directed $\mathbf{E}-\mathbf{W}$, along the coastal areas of south Alicante Province (Spain) that promoted the occurrence of alternating uplifted (e.g. Santa Pola and El Molar Ranges) and subsiding (Santa Pola Lagoon) areas. Flights of marine Quaternary terraces are observed in uplifted areas while subsiding zones host wide lagoons separated from the open sea by beach barriers, at least since Middle Pleistocene times (Fig. 1). The MIS Se sedimentary sequence investigated in this paper is a part of the complex La Marina-El Pinet beach-barrier that is rooted in El Molar Range. The system grew towards the NNE during highstands, with a relatively modest progradation of beach units to the $S / S E$, and accumulation of coastal aeolian dunes (Fig. 2).

The site of La Marina-El Pinet acquired interest since the 1980's, when Bernat et al. (1982), Hearty et al. (1987), and Causse et al. (1993) attempted dating the fossiliferous deposits exposed in a little quarry, later informally called the "classical" quarry by Zazo et al. (2003). The quarry exposes four morphosedimentary units assigned to the Last Interglacial (MIS 5e) that includes three separate highstands (Zazo et al., 2003): the oldest deposited the oolitic facies of Unit 1, the intermediate the mainly bio-siliciclastic Units 2 and 3 separated by a conspicuous erosion surface, and the most recent, the disorganized, coarse-grained Unit 4, capped by a thick calcrete, which lays on an irregular surface that erodes all the former (Fig. 3 A, B, C). Units 1-3 pass landwards into oolitic and siliciclastic aeolian dunes (Fig. 2). All units bear warm Senegalese fauna. A still younger marine terrace was assimilated to MIS 5c/5a. Observations in a nearby quarry, the "new" quarry, placed some $100 \mathrm{~m}$ away, allowed Zazo et al. (2003) and Goy et al. (2006) to obtain a more complete sedimentary succession and new samples for U-series measurements on mollusk shells and on the coral Cladocora caespitosa. Correlation of units exposed in both quarries was established on a schematic way.

Investigations dealing with the chronology of the barrier-spit deposits were firstly concentrated on the "classical" quarry. There, Bernat et al. (1982) carried out the first U-series measurements on $S$. bubonius, and distinguished oolitic and siliciclastic marine facies, although they sampled only the second, younger one. Ages ranging 


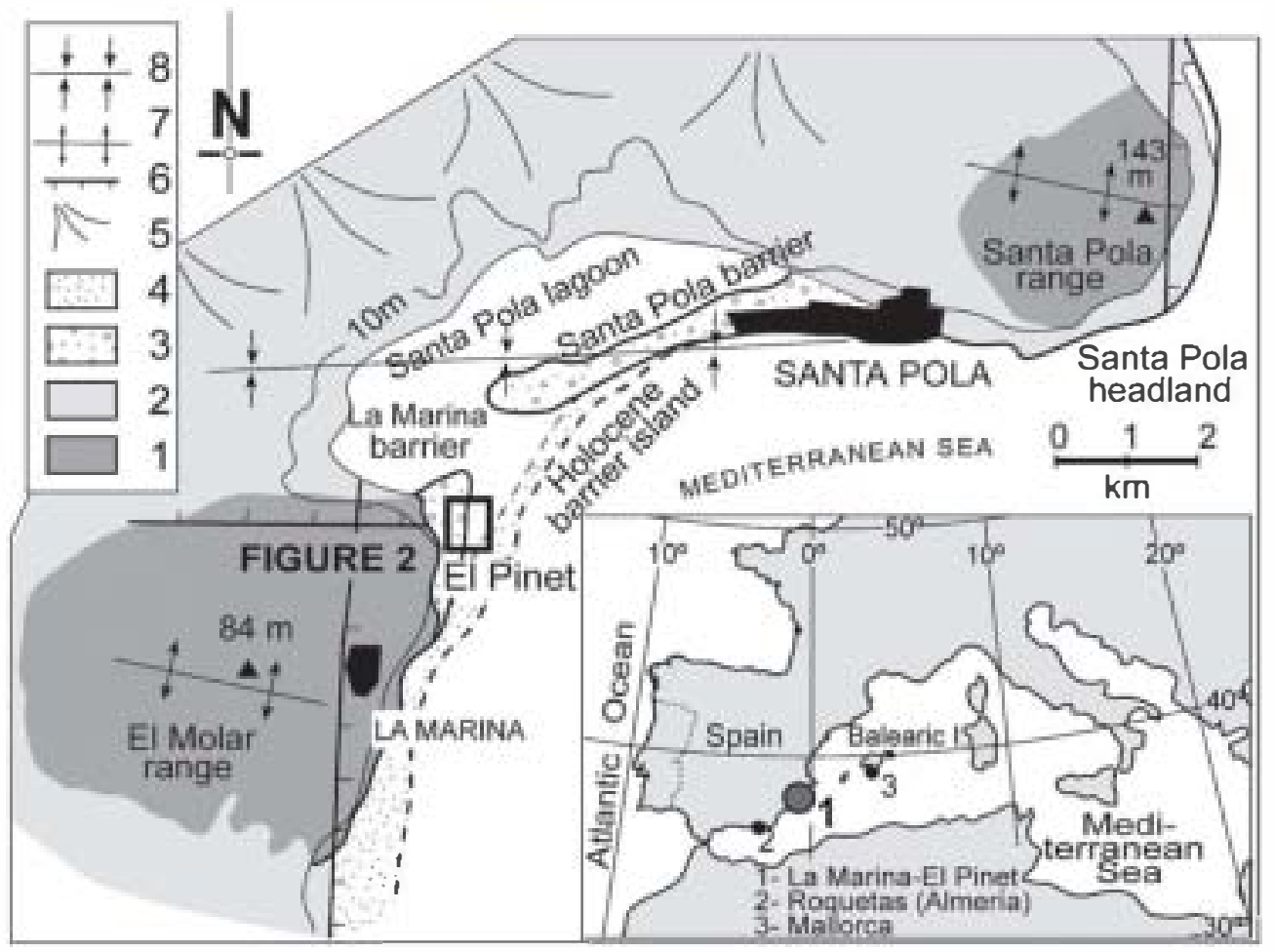

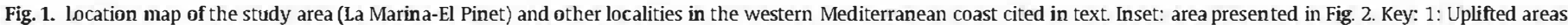

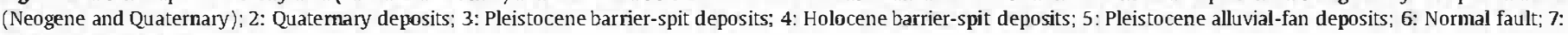
Anticline; 8: Syncline.

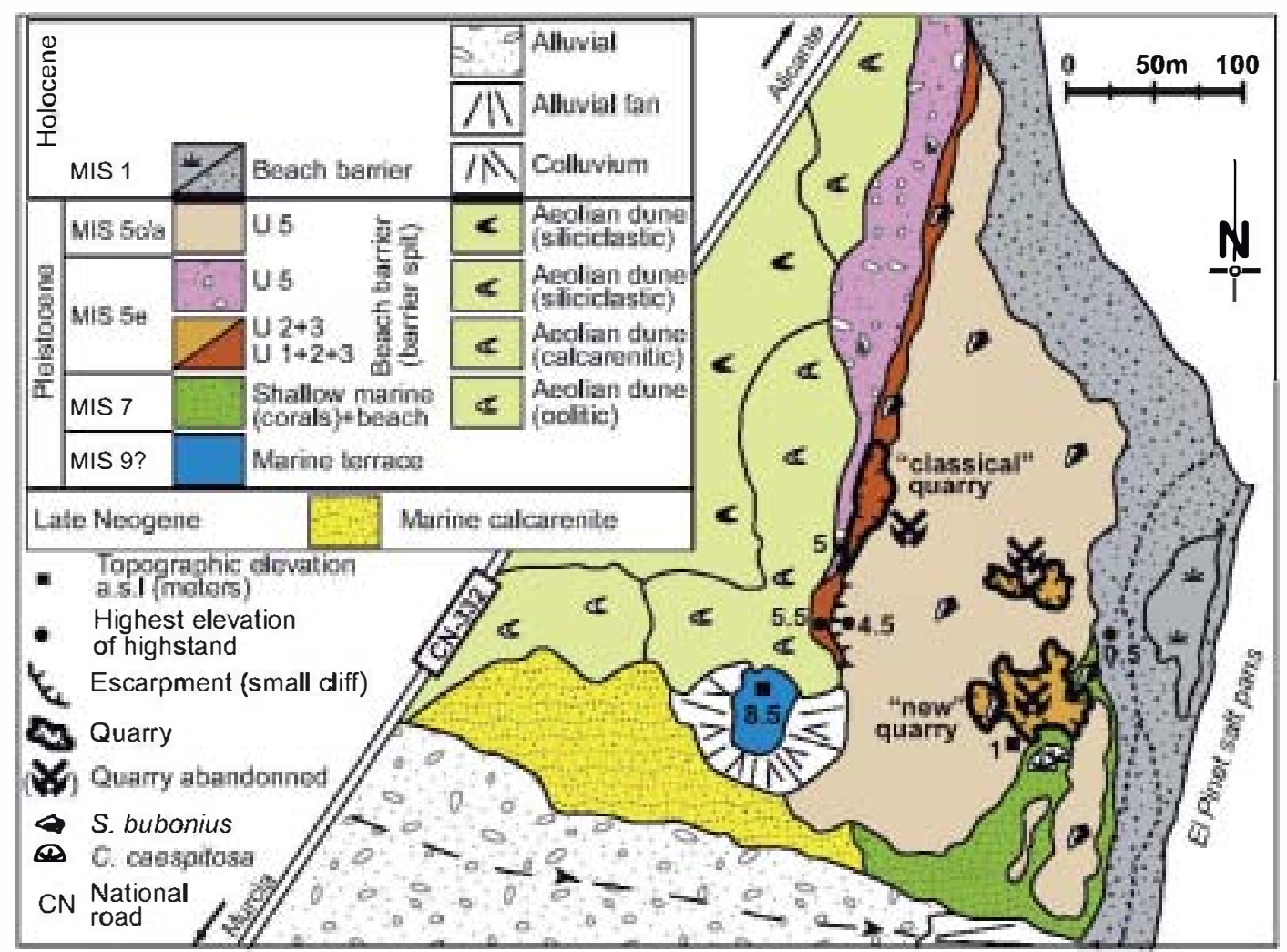

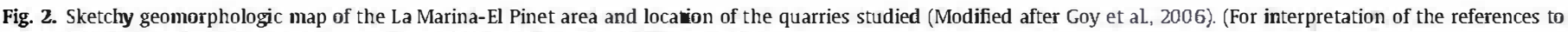
colour in this figure legend, the reader is referred to the web version of this article). 

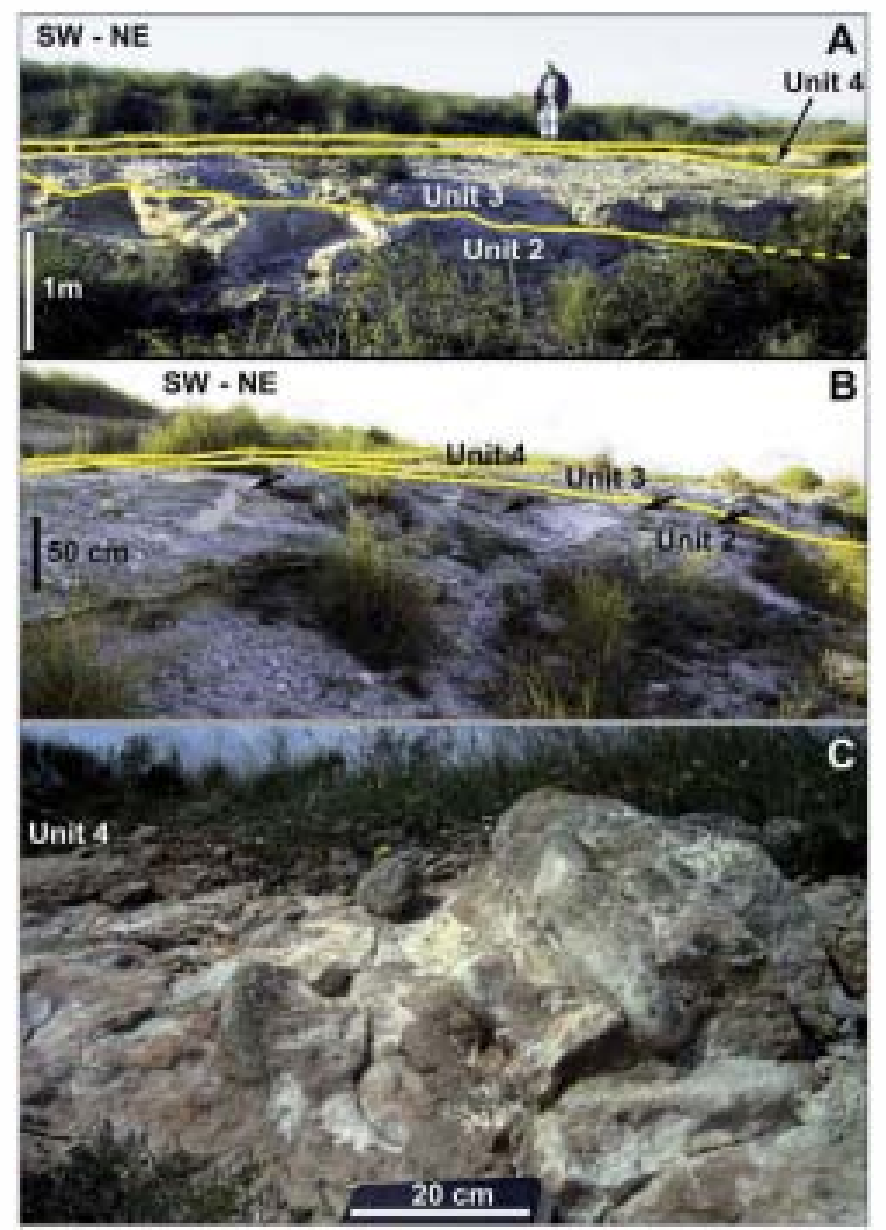

Fig. 3. "Classical" quarry. (A) Units 2,3 and 4. (B) Unit 2, with arrows pointing to plunge-step facies. (C) Unit 4 : boulders embedded in a reddish clayey matrix. (For interpretation of the references to colour in this figure legend, the reader is referred to the web version of this article).

from 150 to $65 \mathrm{ka}$, with a cluster around $98 \pm 5.8 \mathrm{ka}$ led these authors to propose a MIS $5 c$ age for all deposits. Causse et al. (1993) dated two more samples collected from the oolitic Unit 1 (a bivalve shell, UQT. 335, Fig. 4) and the mixed siliciclastic-calcarenitic Unit 2 (a Glycymeris shell, UQT. 336, Fig. 4). Both samples presented secondary uranium fixation and high detritic input and the obtained isochrone age were $\leq 75 \mathrm{ka}$. These authors considered that a large open geochemical $U-T h$ system affected not only these two samples but also the ones dated by Bernat et al. (1982).

Hearty et al. (1987) carried out amino-acid racemization (AAR) analyses at the "classical" quarry. U-series age of $143 \pm 7 \mathrm{ka}$ on the coral C. caespitosa from Cape Huertas (Alicante), a site $\mathbf{4 4} \mathrm{km}$ towards the north in the Mediterranean coast, was used for calibration of Alle/lle ratio. At La Marina-El Pinet they distinguished two marine units (lower and upper), but did not provide lithological descriptions and cross sections. They dated the lower, older unit as aminozones $\mathrm{F}$ and $\mathrm{E}$, and considered the upper unit as aminozone $\mathrm{E}$ (MIS 5e). The origin of aminozone $\mathrm{F}$ was explained by faunal reworking from a unit submerged below present sea level during the time of aminozone $\mathrm{E}$, concluding that the age of both marine units was Last Interglacial, MIS Se.

An excavation window at the floor of the "new" quarry allowed sampling deposits underlying marine units observed at the "classical" quarry: fossiliferous silty sandstone bearing $C$. caespitosa and scattered specimens of S. bubonius. U-series dates (Goy et al., 2006) on $C$. caespitosa yielded mean open-system limit-ages of $170 \pm 10 \mathrm{ka}$ (minimum age) and $237 \pm 20 \mathrm{ka}$ (maximum age), allowing to assign an age of MIS 7a or 7c to these deposits. At the same section, a new sample on $S$. bubonius was collected from the unconformably laying marine Unit 2 for U-Th dating (Fig. 4, sample MP02-7). The resulting U-series age $(93.7 \pm 1.8 \mathrm{ka})$, together with detailed mapping and morphosedimentary analyses, suggested that the marine deposits exposed in La Marina-El Pinet area include the MIS 7 and MIS 5 interglacials along the same section (Goy et al., 2006).

\section{Methodology}

The present investigation in the second highstand of the MIS Se deposits of La Marina-El Pinet quarries focused on:

(a) establishing stratigraphic correlations between the marine units exposed in the two quarries (Fig. 4), because the orientation of the walls (parallel to the ancient coastline in the "classical" quarry and perpendicular in the "new" quarry) allowed reconstructing the geometric and spatial distribution of the terrestrial and marine deposits. The differences in lithology and primary sedimentary structures of the various terrestrial and marine units allowed, after aerial photograph and field examination (scale $1: 5.000$ ), to draw a geomorphological map (Fig. 2) of an area where the maximum elevation is $8.5 \mathrm{~m}$ above the mean high tide watermark. The topographic elevations indicated in the map as a.s.l. were measured with respect to the high watermark, a very reliable datum in these almost-tideless coasts, where astronomical tidal ranges do not exceed $0.25 \mathrm{~m}$. When referring to a highstand, altitude corresponds to the highest elevation of the foreshore-shoreface facies transition (the plunge-step). In the case of the marine terrace, the elevation is that of the inner edge of the terrace marked by a small, usually somewhat degraded, cliff (Fig. 2).

(b) Using 3D architecture and facies analyses of the siliciclastic deposits of the second highstand of MIS Se to investigate the meaning of the erosional surfaces crossing these facies (Fig.4), as related to sea level changes, based on primary physical sedimentary structures. We also checked the spatial distribution and altimetry of upper shoreface and foreshore facies, because in low-energy, sand-dominated coasts the breaker zone is characterized by a step (the plunge step) at the base of the swash zone (Clifton et al., 1971; Davis et al., 1972; Dabrio, 1982). The step forms at water depths between 5 and $15 \mathrm{~cm}$, where back swash meets the breaking waves (Miller and Ziegler, 1968; Dabrio and Polo, 1981; Dabrio et al., 1985). The internal structure of the plunge step is frequently preserved in microtidal sandy beaches as planar cross-bedding directed offshore, with set thickness $10-30 \mathrm{~cm}$, at the seaward side of the foreshore facies (Dabrio et al., 1985; Somoza et al., 1986-87, Bardají et al., 1990; Roep et al., 1998). A further deduction is that, when several of these plunge-step facies are observed inside a given subunit at variable elevations, lateral and vertical shifts of the shoreline can be inferred, and fluctuations of sea level deduced (Fig. 5 A, B, C).

(c) Studying petrographic samples of representative facies collected at the "new" and "classical" quarries analyzed under transmitted, polarized light after impregnation and preparation of thin sections. Cementation and dissolution phases were described and interpreted taking into account the sedimentological and morphological features ofthe sediments. Deductions about subaerial environments of diagenetic features and the relative duration of the cementation processes were checked against those observed in Unit 4, which is encrusted by a thick calcrete that clearly suggests prolonged subaerial exposure.

(d) Comparing with the chronological data from La Marina-El Pinet (see Geological Setting section), which confirm a MIS Se age for 

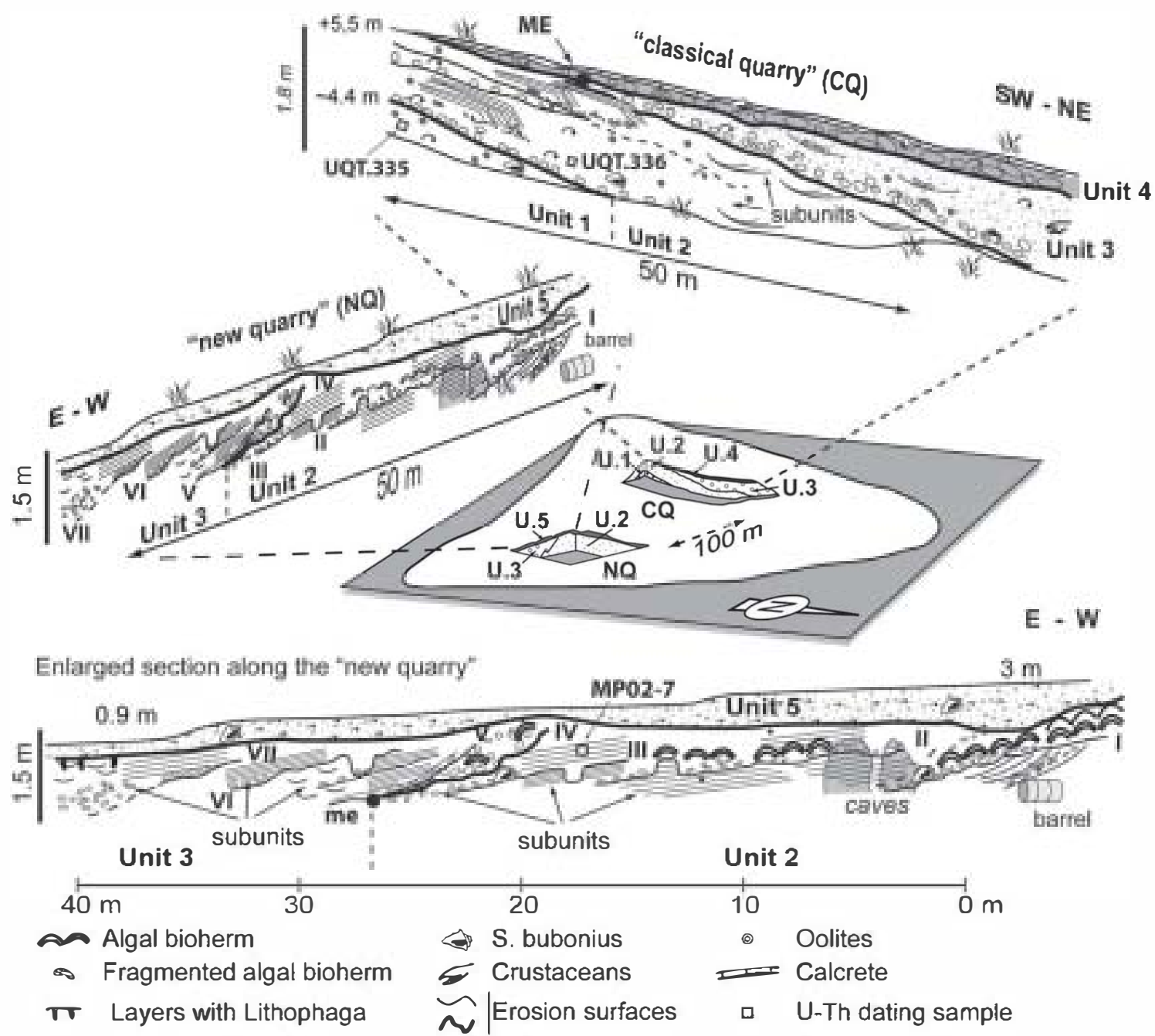

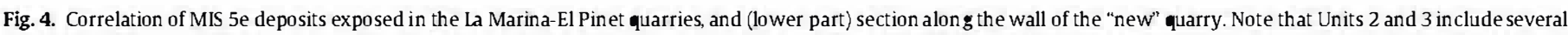

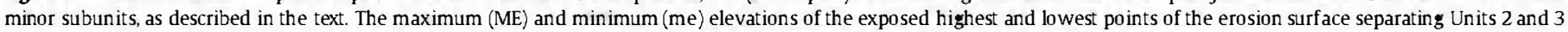
have been indicated. U-series measurements: samples labelled UeT, after Causse et al. (1993), sample MP02-7 after Goy et al. (2006).

the deposits studied in this paper, although they do not supply accuracy about the age of the various highstands. However, integration of our field observations along the Spanish coast and our dating results (Hillaire-Marcel et al., 1986, 1996; Causse et al., 1993; Goy et al., 1997; Zazo et al., 2003; Goy et al., 2006) allows us to assume an average duration of $\sim 10 \pm 2 \mathrm{ka}$ for the second highstand of MIS Se. In La Marina-El Pinet, as in many worldwide coasts, this highstand coincides with the highest sea level reached during the Last Interglacial, when the Mediterranean maximum invasion by warm Senegalese fauna occurred, and large amounts of sediments were deposited. This second highstand is comparable with the sustained MIS Se highstand that occurred between $130 \pm 2$ and $120 \pm 2 \mathrm{ka}$ (Chen et al., 1991; Zhu et al., 1993; Muhs et al., 2002; Mylroie, 2007) and when sea level was 3-6 $\mathrm{m}$ above present.

\section{Results}

\subsection{Sedimentary units}

MIS 5 deposits overlay those of MIS 7 and crop out at certain parts of the floor of the studied quarries (Goy et al., 2006). They consist of five units (Unit 1 to Unit 5) all bearing Senegalese warm fauna. Three of them (Units 1 to 3) are arranged in offlap exposed at the "classical" quarry, whereas only two of these (Units 2 and 3) can be observed in the "new" quarry. Unit 4 onlaps the former and Unit 5 appears staircassed cutting into all the others. According to Zazo et al. (2003), Unit 1 (oolitic) is associated to the first highstand of MIS 5e, Units 2 and 3 (mixed siliciclastic-bioclastic) are related to the second highstand, and Unit 4 represents the third MIS Se highstand (Fig. $3 \mathrm{~A}, \mathrm{~B}, \mathrm{C}$ ). Unit 5 is probably related to MIS 5c/5a.

This paper focuses on the marine Units 2 and 3 from which new textural, petrographical and paleontological analyses are available.

- Unit 2. Consists of siliciclastic medium to coarse bioclastic sandstone and conglomerate, with rhodolithes and abundant remains of the warm Senegalese fauna. This Unit changes landwards to aeolian dunes. In the "classical" quarry, parallel lamination gently sloping to the SE $\left(110-120^{\circ} \mathrm{E}\right)$, grades laterally in that direction into planar cross bedding pointing to the same direction and, then, into wave-ripple cross lamination and wave trough cross bedding (Figs. 4 and 5). Unit 2 is crossed by several irregular erosion surfaces, observed in both quarries, with overall dip to the E-NE, which separate offlaping lithosomes, here called subunits (Figs. 4-6). The disconnection 


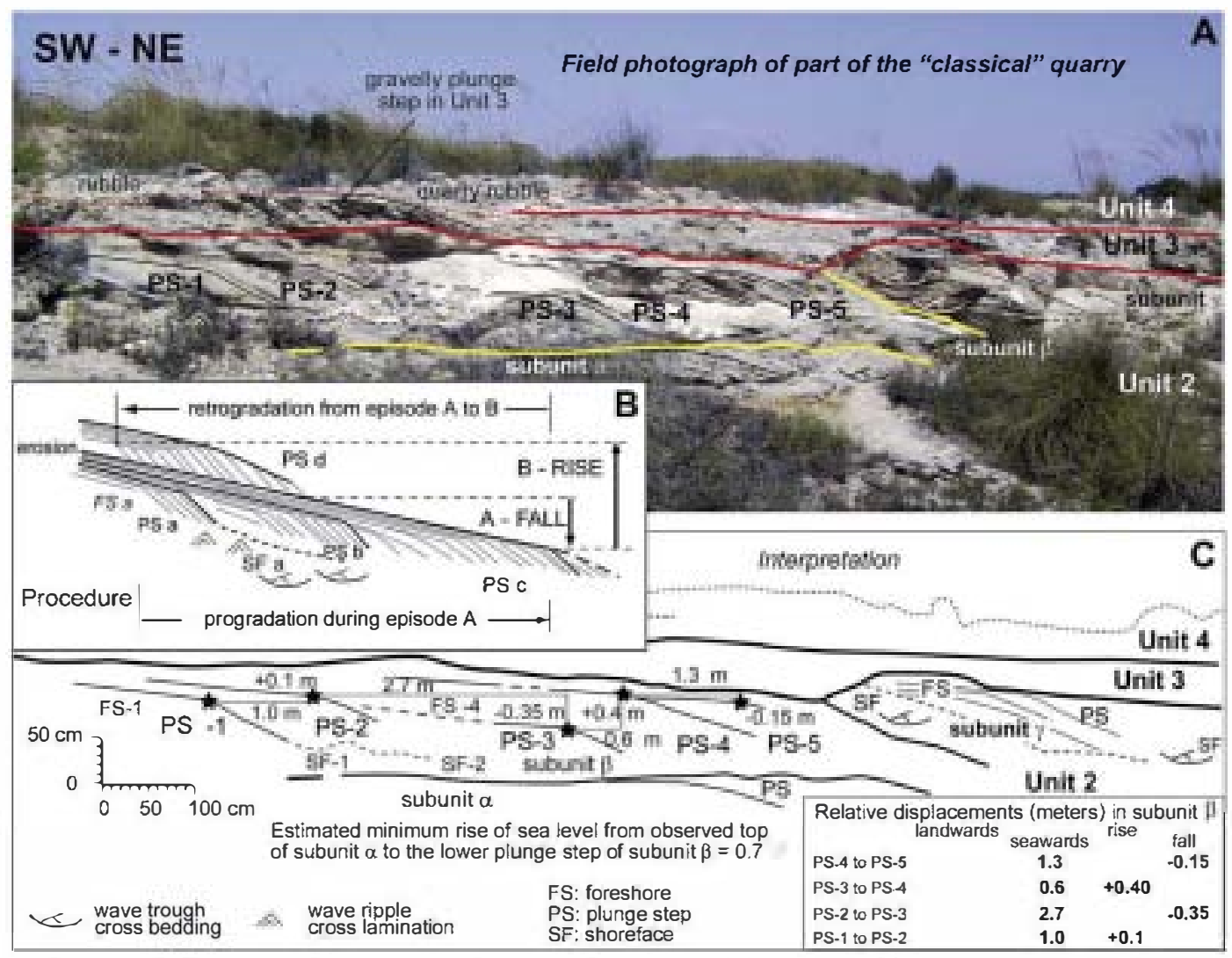

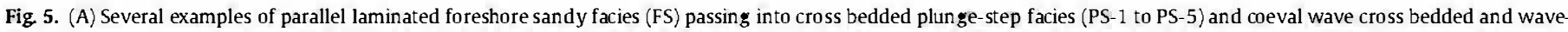

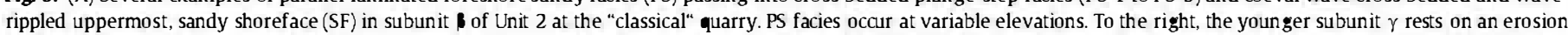

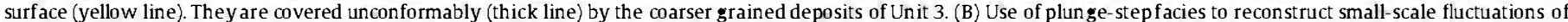

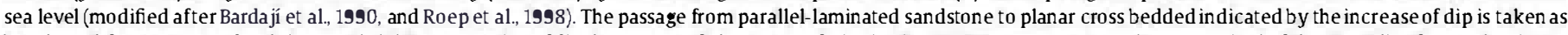

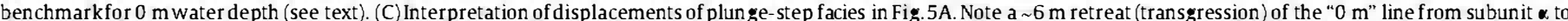

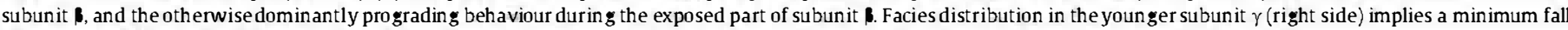
of sea level of $50 \mathrm{~cm}$. (For interpretation of the references to colour in this figure legend, the reader is referred to the web version of this article).

of outcrops makes impossible the desirable correlation between individual surfaces and subunits. Three surfaces have been indentified at the "classical" quarry (see for instance Fig. 5). At the "new" quarry, three highly irregular surfaces which slope exceeds $90^{\circ}$ in some cases are observed. They separate subunits, which typically begin with irregularly spread, conglomerate layers with rounded pebbles. Local patch-like growths (bioherms) of encrusting crinkling, calcareous algae (mainly Lithophyllum sp. and Melobesia sp.) with laminar structure cover indistinctly gravel and the basal erosion surface (where it is not covered by conglomerate). The calcareous algae crusts also include gastropods and bivalves, such as vermetids, Bittium reticulatum and Loripes lacteus. Algae agglutinated bioclastic sand, carbonated rock fragments and scarce oolites. The predominant carbonate cement in these algae crusts is dense peloidal micrite. In some cases, solution vugs with later precipitation of fibrous-radial aragonite are observed in algal and sandstone facies (Fig. $7 \mathrm{~A}$ ). The remaining part of the subunit is parallel laminated, cemented medium to coarse sandstone (Fig. 6).

- Unit 3. It is very much alike Unit 2: It is primarily composed of calcarenites with some coated grains and oolites, and a higher proportion of cemented gravels with rounded pebbles and cobbles (Figs. 3 and 4). In the "classical" quarry, gently-sloping parallel-laminated sandy gravel passes laterally to planar cross bedding pointing to the E/NE Fig. $5 \mathrm{~A}$ ). Internal erosion surfaces very much alike the ones observed in Unit 2 are recognized in both quarries (Figs. 3 and 6) separating offlapping subunits or lithosomes similar to those found in Unit 2, with progradation to the E-NE $\left(\mathrm{N} 40-70^{\circ} \mathrm{E}\right)$. Encrusting algal growths are scarcer than in Unit 2. The base of Unit 3 is markedly irregular in both quarries: at the "new" quarry erosion penetrated downward a minimum exposed of $1.5 \mathrm{~m}$. The erosion surface is covered by a coarse-grained conglomerate with grain sizes pebbles and cobbles (Figs. 4 and 6).

The much more pronounced and deep-incised erosion surface IV (Fig. 3 and 5) has been recognized as the limit between units 2 and 3. An additional criterion is that in Unit 3 the percentage of conglomerate facies increases sharply and, in thin-section, rock fragments are more diverse and the proportion of quartz and poorrounded grains is higher.

Several samples collected below the erosion surfaces inside Units 2 and 3 at the "new" quarry show a first precipitation of geopetal and meniscus spar, (Fig. 7 B, D, E), followed by partial dissolution of metastable carbonates (Fig. 7C-E), partial leaching of red algae (Fig. $7 \mathrm{C}$ ), and precipitation of micrite as irregularlyshaped coatings forming bridges between grains, or as irregular peloidal accumulations in pores (Fig. 7 B, D). Sediments laterally linked to the algal patches or just above them also include meniscus spar cements, with a second cement of clotted peloidal micrite (Fig. 7 F) or dense micrite like those of the algal growths. Some samples show a third cementation phase characterized by fillingpore irregular micritic matrix (Fig. 7 F). 


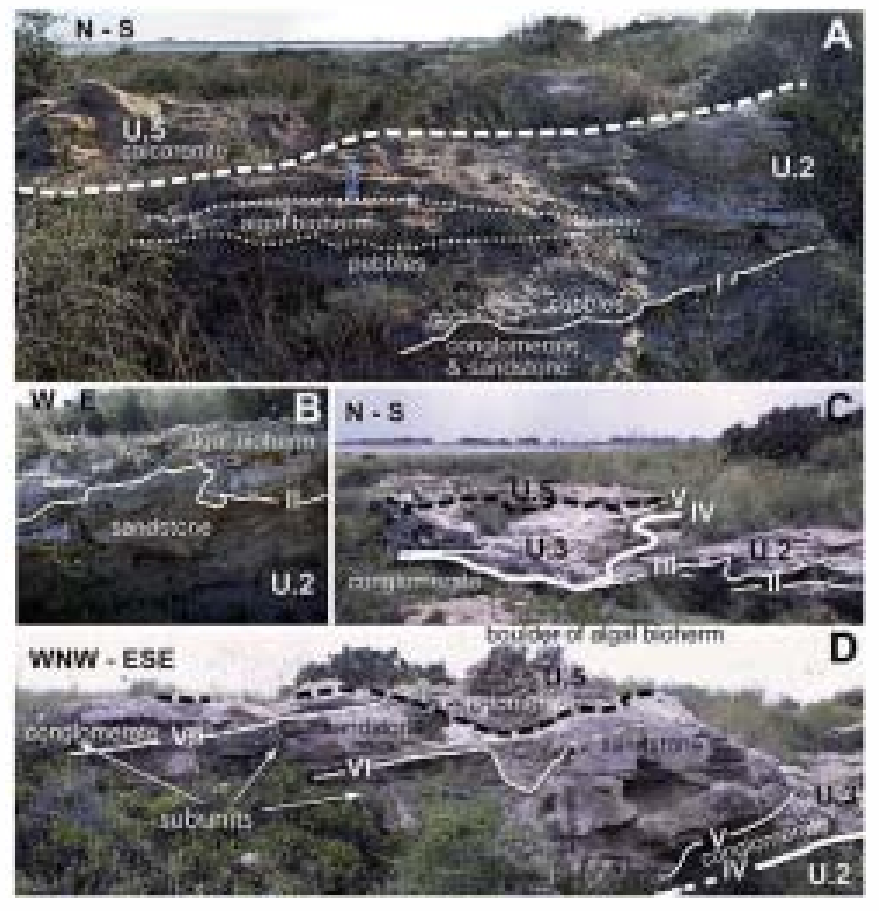

Fig. 6. Erosional surfaces I to VII separating subunits inside Units 2 and 3 at the "new" quarry. (A): The lowermost erosional surface (I) overlain by cobbles, pebbles and the oldest algal bioherm found in the quarry. (B): Erosional surface 11 covered by conglomerates and the second recognized algal bioherm that extends laterally for more than $3 \mathrm{~m}(\mathrm{C})$ : Several erosional surfaces (ll to $\mathrm{V}$ ); the most prominent, and deeply incised (IV) marks the limit between Units 2 and 3. (D): Erosional surfaces (IV to VII) in Unit 3 at the southern part of the quarry. The thick, dashed line indicates the erosional limit with the overlying calcarenite Unit 5 that locally includes boulders of algal biohermal limestone (photo graph D) presumably removed from the underlying units. (For interpretation of the references to colour in this figure legend, the reader is referred to the web version of this article)

Samples of Units 2 and 3 taken in the "classical" quarry show similar diagenetic features. Initial vadose spar cements can be observed followed by solution processes related to subaerial environments, together with later accumulations of irregular micritic matrix (Fig. $7 \mathrm{G}$ ).

The petrographic features were compared with those of Unit 4, in which thick encrusting calcrete clearly suggests prolonged subaerial exposure, and with the bioherms, related to submarine environments. Comparison was intended as a means to obtaining some clues about subaerial or submarine diagenetic environments, and the relative duration of the cementation processes. Small pisolite-like coated grains (Fig. $7 \mathbf{H}$ ), precipitation of oxides, laminated micritic crusts, and partial or total dissolution of metastable carbonates in the red matrix and carbonate crust in Unit 4, indicate subaerial alteration processes (see e.g.: Wright, 1994, and Caron et al., 2009). The obtained deductions fit the morphological characteristics and stratigraphic positions of these units.

\section{Interpretation and discussion}

5.1. Correlation of facies: the beach profiles during sedimentation of Units 2 and 3

As facies exposed at each quarry depend on their position relative to the paleo-shoreline (Fig. 8), correlation of the two quarries allowed the reconstruction of an evolutionary beach model across the ancient barrier-spit system, as well as patterns of progradation.
At the "classical" quarry, the internal structure of the coastal facies in each subunit is interpreted as the foreshore, plunge step, and uppermost shoreface of microtidal, reflective beaches (see e.g., Dabrio et al., 1985). In contrast, facies associations in all subunits of the "new" quarry are dominantly parallel-laminated. Considering the more external (seaward), and topographically-lower position of the "new" quarry facies associations are interpreted as deposited on the shallow shoreface, inside the photic zone required by algae to grow. The overlying parallel-laminated sandstones are interpreted as foreshore facies.

Thus, our reconstruction of the coast during deposition of each subunit within Units 2 and 3 consists of a gravelly, mostly sandstarved shoreface, with local growths of algal bioherms. It passed landward to a sand-richer uppermost shoreface and foreshore (Fig. 8.1).

\subsection{Sea-level fluctuations: facies distribution, magnitude and timing}

In our interpretation, the sea covered the area presently occupied by the quarries during the successive phase of high sea level that deposited the various subunits of Units 2 and 3. Sand accumulated mostly on the topographically highest parts of the area (the present "classical" quarry) where the uppermost shoreface, breakers and foreshore zones could be distinguished. A large part of the shoreface remained relatively starved of sand, and the gravelly bottom was colonized by algal bioherms that encrusted the bottom fixing the loose gravel pebbles (the present "new" quarry). During the first part of the phase of high sea level, minor (tens of centimeters high) fluctuations of sea level were recorded as vertical and lateral shifts of the plunge-step facies, as observed at the "classical" quarry (Figs. 5 and 8 ). After some time, the balance displaced towards progradation of the sandy beach, with stable/gently falling sea level as suggested by overall geometry, relative elevations of deposits, and the superposition of sandy foreshore over the gravelly shoreface facies (Fig. 8.2). Continued fall allowed progressive subaerial exposure and erosion. This pattern was repeated at least seven times producing erosion surfaces I to VII that limit the successive subunits (Figs. 4 and 6 ).

The cementation processes observed in the shoreface-foreshore sediments of the "new" quarry were interpreted taking into account the marine phreatic cements of the algal growths (Fig. $7 \mathrm{~A}$ ), and the diagenetic characteristics of subaerial exposure recorded in the Units 4 and 5 (Fig. $7 \mathrm{H}$ ). Samples collected below erosional surfaces inside Unit 2 or Unit 3 show a first precipitation of geopetal and meniscus spar (vadose environment) related to the progradation of the beach (Fig. 7 B, D, E). A second precipitation of irregular micrite coatings appears related to the partial dissolution of metastable carbonates, leaching of red algae fragments, and corrosion of margins of bioclasts and previous vadose cements (Fig. 7 B, C, D, E). The later features are interpreted as incipient alteration and cementation in subaerial environment (Caron et al., 2009), and record a change from marine vadose conditions to a subaerial meteoric vadose environment, implying subaerial exposure. As cements and dissolution processes are less developed than in Units 4 and 5, we deduce that marine deposits of Units 2 and 3 underwent a shorter exposition to meteoric environmental conditions. Therefore, the areas of the beach placed at higher elevations were the first to become subaerially exposed, weathered and, probably, eroded even when the beach was still prograding (Fig. 8.2). Eventually, emersion affected the whole area of the investigated quarries.

Renewed rise of sea level brought the shoreline to elevations similar to the previous, underlying subunit. We assume that the rise was rapid because we did not observe remains of foreshore or 

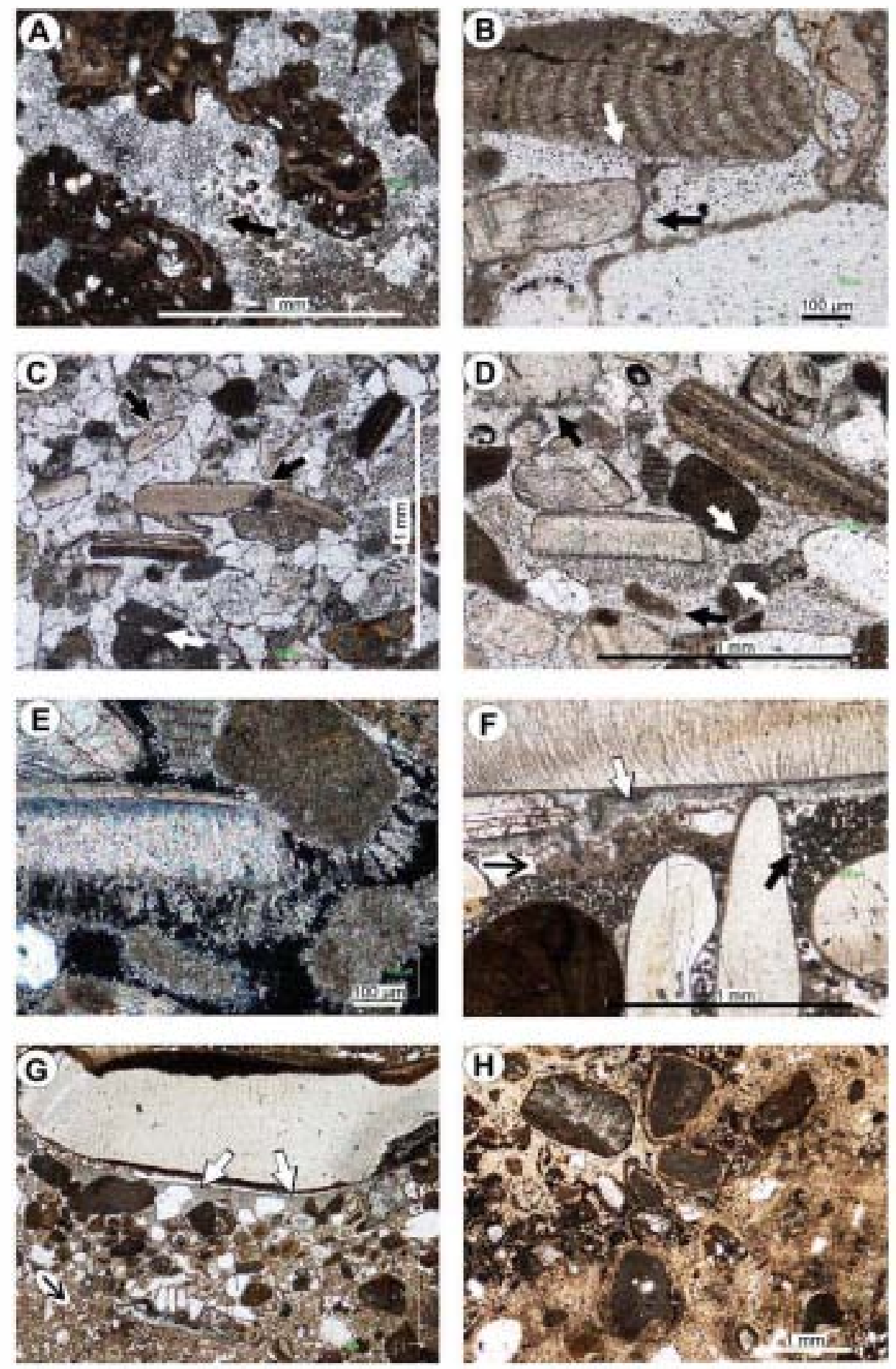

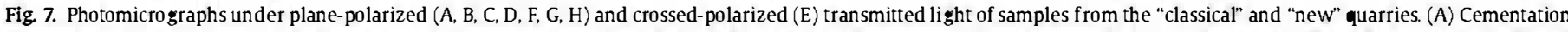

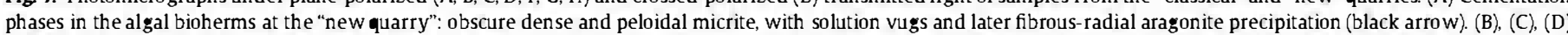

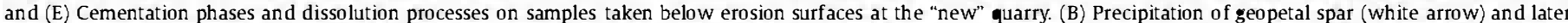

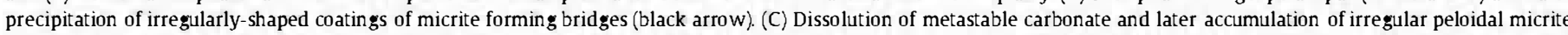

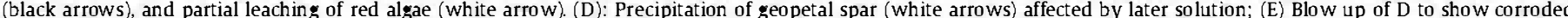

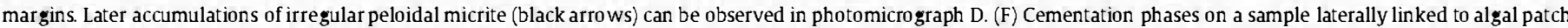

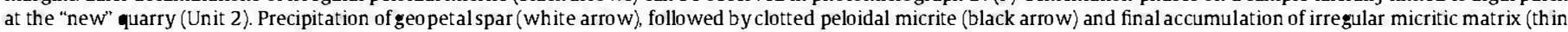

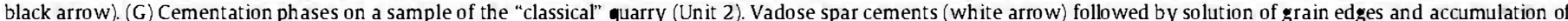

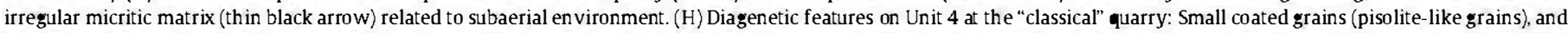

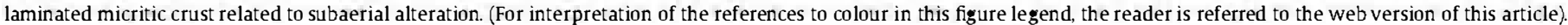

uppermost shoreface facies sandwiched between the erosion surface and the gravelly shoreface deposits.

The minimum magnitude of sea-level fluctuation necessary to generate the erosion features and the overlying deposits of each subunit has been calculated marking three key points in a laterally continuous outcrop ( $X, Y$ and $Z$, Figs. 8.2). $X$ is the minimum observed elevation during the sea-level rise; $Y$, the maximum preserved elevation of deposits of this particular subunit, and $Z$, the 


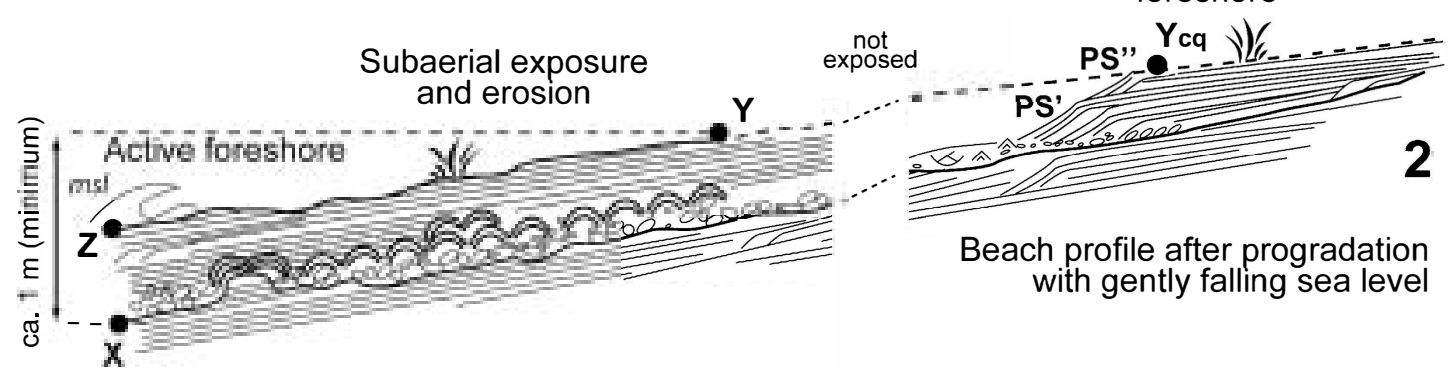

Active foreshore

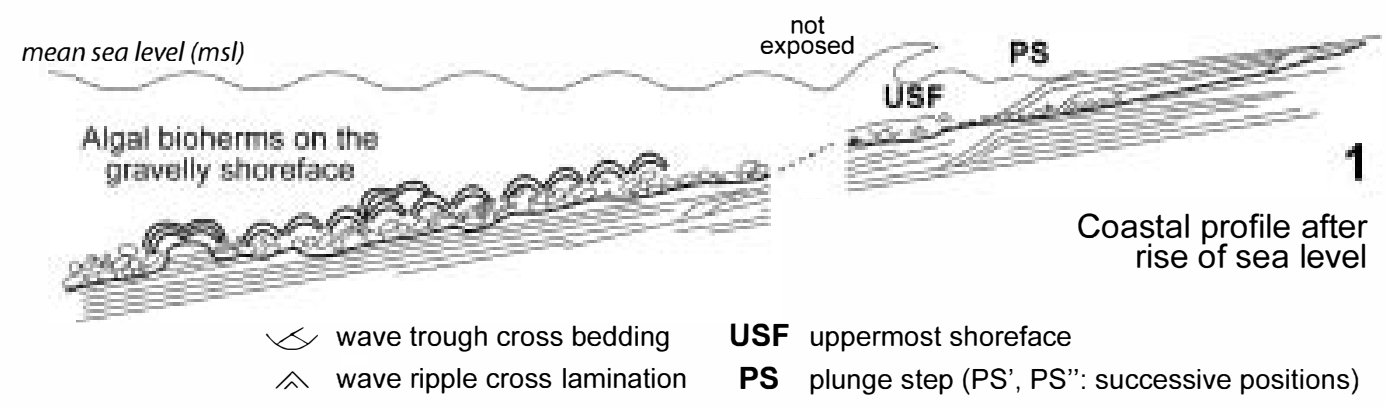

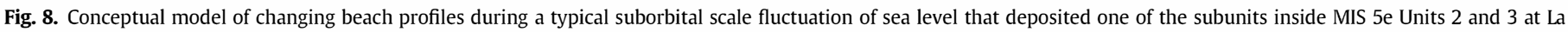

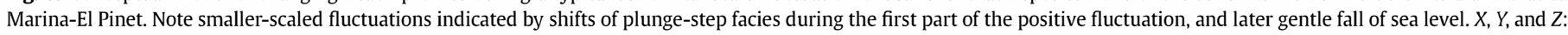

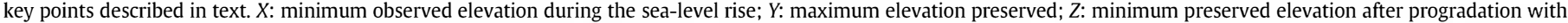

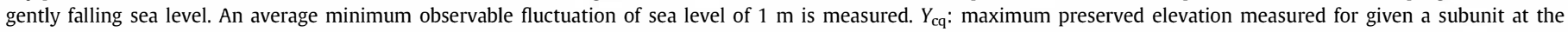
"classical" quarry.

minimum preserved elevation of the same deposits after progradation with gently falling sea level. In this way, we obtain the approximate position of sea level at three moments of the evolution, and a minimum observed difference of sea level of $1.0 \mathrm{~m}$ is measured. Unfortunately these values must remain as a minimum inference owing to two uncertainties: (a) Deposits and other morphological features connected to the maximum fall of sea level are not exposed, and lay below the quarry floors and the present water table. (b) In this most conservative calculation, we did not include the observations in the "classical" quarry because we could not trace univocal correlations for every subunit owing to lack of suitable outcrops. However, it is evident that the sea level rose to this area and deposited subunits during Units 2 (subunits $\alpha, \beta$, and $\gamma$ ) and 3 (Fig. 5). This means that new " $Y_{\mathrm{cq}}$ " points can be placed there (Figs. 8-2), and hence, that the likely values for sea level oscillations during deposition of subunits and the intervening erosion surfaces must be increased to around $2 \mathrm{~m}$. In summary, the relatively rapid rises of sea level that begun sedimentation of subunits were followed by a period of essentially high level, with minor oscillations recorded as shift of plunge-step facies, and later gentle, relatively slow fall. Therefore, the investigated sequences record at least two orders of small-scale changes of sea level.

This pattern of more or less homogeneous, repeated fluctuations was interrupted by a notable fall of sea level of at least $3-3.5 \mathrm{~m}$ that produced the prominent erosion surface IV (Fig. 6) that cuts across the underlying deposits, separating Units 2 and 3. Comparison of the relative elevations of the highest point of the surface in the highest part of the "classical" quarry (Fig. 4, point $M E$ ) and the lowermost point of the "new" quarry (Fig. 4, point me) suggests a minimum observed fall of sea level of $3-3.5 \mathrm{~m}$, followed by a new rise of at least the same magnitude. This implies a total sea-level change of at least 6-7 $\mathrm{m}$ occurred during the fall and subsequent rise between Units 2 and 3. Besides, this remarkable fall of sea level promoted a renewed input of pebbles fed to the coast, probably trough fluvial incision and erosion of older beach deposits. Our conclusion is that sea level rose and fell repeatedly during the second highstand of MIS 5e, reaching similar elevations a.s.l., and depositing Units 2 and 3 and their various subunits.

Assuming an average duration of $10 \pm 2 \mathrm{ka}$ (see Methodology section) for the second highstand of MIS 5e, and that at least seven (I to VII) erosional surfaces are exposed at the "new" quarry (Fig. 3), separating eight visible subunits, an average millennial-submillennial duration $(\sim 1.0 \mathrm{ka})$ can be calculated for every event of progradation and erosion, with associated changes of sea level of at least $2 \mathrm{~m}$. Notwithstanding the significant fall and subsequent rise of sea level $(\sim 6-7 \mathrm{~m})$ that generated the erosion surface recorded between Units 2 and 3, we assume that the timing of this oscillation was not necessarily longer than those that generated the erosion surfaces limiting subunits. This fluctuation inside the second MIS 5e highstand should be comparable to that recorded around $124 \mathrm{ka}$ in coral terraces, which lasted 1000-1500 yr (White et al., 1998). A regression around 125-124 ka has been also registered in The Bahamas and Bermuda (Hearty and Kindler, 1995) and in the global sea-level curve proposed by Hearty et al. (2007).

The proposed model of coastal evolution involves a relatively continuous, but slow process with times of high sea levels during which smaller-scaled fluctuations of sea level led to deposition of various sets of foreshore facies with shifting positions that can be traded using the displacements of plunge-step facies. As plungestep facies are swept by storm waves, the preservation of several of these lateral changes in the "classical" quarry proves that individual 
storm surges likely to be in the realm of extreme wave events that occur associated with sea level extremes were not the driving mechanism of the described evolution. Sea level extremes are usually generated by a combination of tides and storm surges due to the action of atmospheric pressure and wind.

Plausible present-day analogues of occurrence and spatial and temporal variability of this process are sea level extremes in southern Europe. These have been explored using 73 tide gauge records from 1940, including three Spanish eastern Mediterranean coasts: Catalonia, Valencia and Alicante (Marcos et al., 2009). Maximum sea-level extremes in this area ranged from 20 to $60 \mathrm{~cm}$, much lower than in northern Adriatic $(200 \mathrm{~cm})$ and Gabes Gulf $(160 \mathrm{~cm})$. The average duration of these events hardly surpasses a few hours. One of the most extremes storms of the last years in western Mediterranean occurred between the 10th and 16th of November 2001. Strong northern winds, high waves and extreme surge were recorded and produced severe damage in the coast, including Spain, not only for their intensity, but also for their persistence, as the event lasted 5-6 days (Gómez et al., 2002).

On the other hand, widespread occurrence of shifting plungestep facies, particularly evident in the "classical" quarry (Fig. 3 B, and 5) implies that sea level fluctuated during the accumulation of each subunit, with amplitudes in the order of tens of centimeters (Fig. $5 \mathrm{C}$ ). We assume that the temporal scale of these changes is similar to the accumulation of beach crests, which accrete with decadal periodicity, which origin has been related to NAO (Rodríguez-Ramírez et al., 2000; Goy et al., 2003) and the solar double Halle cycles (Goy et al., 2003).

Global sea level and Earth's climate areclosely linked. Millennialscale sea-level fluctuations have been recorded through MIS Se interglacial (e.g. White et al., 1998; Andrews et al., 2007; Hearty et al., 2007). Rapid ice melting and ice build up have been invoked as the main cause for such rapid sea level variability. However, contribution from different driving mechanism such as: solar variability, a weakened or southward displaced North-Atlantic current, and the relative importance of northern and southern hemispheres ice growth and decay remain under debate (Andrews et al., 2007).

A pervasive suborbital climate variability has been repeatedly cited during the Last Glacial, extending back to the MIS Se (Bond et al., 1997, 2001) based on findings in North Atlantic region. Cycles with duration of ca $1.5 \mathrm{ka}$ were linked to perturbations in solar energy output, but Broecker et al. (2001) and McManus et al. (1999) suggested that changes in ocean circulation must have contributed as well. Recent land records show similar climate variability during the warmest part of MIS Se (e.g. Eemian period). Stable Oxygen and Carbon isotope ratios from a speleothem in south-west France showed prominent submillennial-scale climate fluctuations during this period (Couchoud et al., 2009). Similar results were obtained from other speleothem recovered in Tuscany, Italy (Drysdale et al., 2009). Eemian pollen data from lake sediments in southern Germany (Müller et al., 2005) have also revealed cyclic climate variability during the interval 126 to $110 \mathrm{ka}$. Pollen data suggest that this warm period was punctuated by 11 cold events, with an average spacing of $1.1-1.5 \mathrm{ka}$, related to cyclic changes in mean winter climates. These values are in the range of the deduced by us for La Marina-El Pinet.

It should be most desirable to compare the data reported in La Marina-El Pinet with other interglacials located in areas nearby to minimize the local effects. Unfortunately, no reports of similar changes of sea level in interglacials older than MIS Se have been published. The only comparable case-study available is a Holocene coastal plain, where a barrier-spit system prograded in Roquetas (Almeria coast) during the most stable part (the last $7 \mathrm{ka}$ ) of the present interglacial. Goy et al. (2003), Zazo et al. (2008), and Fernández-Salaset al. (2009) distinguished six periods of remarkable progradation ( $H_{1}$ to $H_{6}$ ), repeated more or less every 1.4 to $3.0 \mathrm{ka}$, punctuated by shorter, centennial periods (lasting 600 to $270 \mathrm{yrs}$ ) of reduced progradation. These recurring short periods were interpreted as climatically-influenced and record increased aridity and relative low sea level, coincident with cold Bond events (Bond et al., 1997) and low sea surface temperatures (De Menocal et al., 2000; Cacho et al., 2001). Increased aridity following these cold events was also registered in the abundance of steppic taxa in vegetation of southern Iberian Peninsula (Fletcher et al., 2007).

We think that phases of progradation in Roquetas and La MarinaEl Pinet were comparable, and that the $H$ sedimentary units of Goy et al. (2003), Zazo et al. (2008), and Fernández-Salas et al. (2009) are equivalent to the subunits described in this paper, but the scale of the vertical changes of sea level is greater in La Marina: $0.8-1 \mathrm{~m}$ vs. $2 \mathrm{~m}$ respectively. The short arid periods during the Holocene are comparable with the lowest sea levels in La Marine-El Pinet. Changes in the direction and intensity of prevailing winds were invoked as the prime factors controlling coastal progradation in Roquetas (Zazo et al., 2008). However, in the Pleistocene case study, the larger magnitude of the repeated sea level oscillations, with a total change of sea level of at least 4-7 $\mathrm{m}$ during the fall and subsequent rise involved in the genesis of subunits suggests a necessary contribution from rapid ice sheets melting and build-up.

\section{Conclusions}

Evidence of rapid changes of sea level during the second MIS 5e highstand, comparable to the "sustained MIS Se highstand" with a duration of $10 \pm 2 \mathrm{ka}$, has been recognized in a prograding barrierspit system located at Ia Marina-El Pinet (Alicante). Detailed sedimentological analysis allowed differentiating three orders of sealevel fluctuations.

The largest-scaled fluctuation is recorded as the conspicuous erosion surface (IV) and the associated increase in grain size that divides deposits of the second highstand in two morphosedimentary units: Unit 2 and Unit 3. It involved a minimum total sea level variation of $6-7 \mathrm{~m}$.

These units include eight prograding subunits separated by less prominent erosion surfaces. Petrographic analysis of marine sediments below and above the surfaces revealed that subaerial exposure took place after deposition of each subunit. In our interpretation, the erosion surfaces are the result of repetitive relatively slow falls of sea level followed by rapid sea-level rise. The minimum amplitude deduced for fluctuations is $2 \mathrm{~m}$, which represents a total change (fall and subsequent rise) in sea-water of $4 \mathrm{~m}$. After each fall and erosion the sea level rose to similar topographic elevations. We propose a millennial or submillennial periodicity $(\sim 1 \mathrm{ka})$ for these fluctuations, and disregard storm surges as a likely generating mechanism. The large magnitude of the repeated sea-level fluctuations suggests a contribution by rapid ice sheets melting and build-up.

The smaller-scaled (tens of centimeters) order of oscillations of sea level has been recognized inside the subunits from shifts of the foreshore and uppermost shoreface facies, and a decadal periodicity is suggested.

\section{Acknowledgements}

Research Projects CGL08-03998BTE, CGI08-04000BTE, Consolider-Ingenio CSD2007-00067-GRACCIE, AECI-A/017978/08 and NEAREST-UE-GOCE-037110. UCM Research Group 910198 (Paleoclimatology and Global Change); GEOTOP Iab. Contrib. IGCP 588 and 495. INQUA Project 0911 and INQUA Coastal and Marine Processes Commission. 
Accordi, G., Brillia, M., Carbonea, F., Voltaggioa, M., 2010. The raised coral reef complex of the Kenyan coast: Tridacn gigas U-series dates and geological implications. Journal of African Earth Sciences 58, 97-114.

Andersen, M.B., Gallup, C.D., Scholz, D., Stirling, C.H., Thompson, W.G., 2009. U-series dating of coral reefs: Consensus and controversy. Pages News 17, 54-56.

Andrews, J.E., Portman, C., Rowe, P.J., Leeder, M.R, Kramers, J.D., 2007. Sub-orbital sea-level change in early MIS 5e: new evidence from the Gulf of Corinth, Greece. Earth and Planetary Science Letters 259, 457-468.

Bardaji, T., Coy, J.L., Somoza, L, Zazo, C, Dabrio, C.J., 1990. Pleistocene fan deltas in southeastern Iberian Peninsula: sedimentarycontrols and sea level changes. In: Colella, A., Prior, D. (Eds.), Coarse-grained Delws. Spec. Publ. International Association of Sedimentologists, 10. Blackwell Science, pp. 129-151.

Bardaji, T., Goy, J.L., Zazo, C., Hillaire Marcel, C., Dabrio, C. J., Cabero, A., Ghaleb, B. Silva, P.G., Lario, J., 2009. Sea-level and climate changes during IS 5 in western Mediterranean (Spain). Geomorphology 104, 22-37.

Bernat, M., Echailler, J.V., Busquet, J.C., 1982. Novelles datations I0-U sur des Strombes du Dernier Interglaciaire en Méditerranée. Comptes Rendues de la Académie de Sciences de Paris II 295, 1023-1026.

Bernat, M., Paskoff, R, Sanlaville, P., 1985. Dating of marine terraces from the east coast of Tunisia. lo-U method applied to fossil molluscs shells. An example of sub-actual contamination. Revue de Geologie Dynamique et de Geographie Physique 26 (3), 157-161.

Blanchon, P., Eisenhauer, A., 2001. Multi-stage reef development on Barbados during the Last Interglacial. Quaternary Science Reviews 20, 1093-1112.

Bond, G., Showers, W., Cheseby, M., Lotti, R, Almasi, P., Demenocal, P., Priore, P., Cullen, H., Hajdas, I., Bonani, G., 1997. A pervasive millennial-scale cycle in north Atlantic Holocene and glacial climates. Science 278, 1257-1266.

Bond, G.C., Kromer, B., Beer, J., Muscheler, R, Evans, M.N., Showers, W., Hoff mann, S. Lotti-Bond, R., Hajdas, I., Bonani, G., 2001. Persistent solar influence on North Atlantic climate during the Holocene. Science 294, 2130-2136.

Broecker, W., Southerland, S., Peng, T.-H, 2001. A possible 20th-century slowdown of southern ocean deep water formation. Science 286, 1132-1135.

Cacho, I., Grimalt, J.O., Canals, M., Shacklevon, N., Schönf eld, J., Zahn, R., 2001. Variability of the Western Mediterranean Sea surface temperature during the last 25000 years and its connection with the Northern Hemisphere climatic changes. Paleoceanography 16, 40-52.

Caron, V., Bernier, P., Mahieux, G., 2009. Record of late pleistocene (exygen Isotopic Stage 5) climate changes during episodes of karst development on the northern coast of crete: sequence stratigraphic implications. Palaeogeography, Palaeoclimatology, Palaeoecology 277 (3-4), 246-264.

Causse, Ch., Goy, J.L., Zazo, C., Hillaire-Marcel, C., 1993. Potentiel chronologique (Th/U) des faunes pléistocènes méditerranéennes: exemple des terrasses marines des régions de Murcie et Alicante (Sud-est de I'Espagne). Geodinamica Acta $6(2), 121-134$.

Chen, J.H., Curran, H.A., White, B., Wasserburg, G.J., 1991. Precise chronology of the Last Interglacial period: ${ }^{234} \mathrm{U}-{ }^{230} \mathrm{Th}$ data from fossil coral reefs in the Bahamas. Geological Society of America Bulletin 103, 82-97.

Clifton, H.E., Hunter, RE., Phillips, RW., 1971. Depositional structures and processes in the non-barred high-energy nearshore. Journal of Sedimentary Petrology 41 , 651-670.

Couchoud, I., Genty, D., Hoffmann, D., Drysdale, R, Blamart, D., 2009. Millennialscale climate variability during the Last Interglacial recorded in a speloothem from south-western France. Quaternary Science Reviews 28, 3263-3274.

Dabrio, C.J., Polo, M.D., 1981. Flow regime and bedforms in a ridge and runnel system, SE Spain. Sedimentary Geology 28, 97-110.

Dabrio, C.J., Coy, J.L., Zazo, C., 1985. A model of conglomeratic beaches in tectonically active areas (Late Pleistocene-actual Almeria, Spain). In: Proceedings 6th European Regional Meeting I.A.S. International Association of Sedimentologists, Lleida, pp. 104-107.

Dabrio, C.J., 1982. Sedimentary structures generated on the foreshore by migrating ridge and runnel systems in microtidal and mesotidal coasts, S Spain. Sedimentary Geology 32, 141-151.

Davis, R.A.J.R, Fox, W.T., Hayes, M.๑., Boothroyd, J.C., 1972. Comparison of ridge and runnel systems in tidal and non-idal environments. Journal of Sedimentary Petrology 42, 413-421.

De Menocal, P., Ortiz, J., Guilderson, T., Sarnthein, M., 2000. Coherent high-and lowlatitude climate variability during the Holocene warm period. Science 288. 2198-2202.

Drysdale, R.N., Hellstrom, J.C., Zanchetta, G., Fallick, A.E., Sánchez Goñi, M.F., Couchoud, 1., McDonald, J.s Maas, R., Lohmann, G., Isola, I., 2009. Evidence for obliquity forcing of glacial Termination ll. Science 325, 1527-1531.

Dumas, B., Hoang, CT. Raffy.J., 2006. Record of MIS 5 sea-level highstands based on $\mathrm{U} /$ The dated coral terraces of Haiti. Quaternary International 145-146, 106-118.

Fernández-Salas, L.M., Dabrio, C.J., Goy, J.L., Diaz del Rio, V., Zazo, C., Lobo, F.J., Sanz, J.L., Lario, J., 2009. Land-sea correlation between late Holocene coastal and inf ralittoral deposits in the SE Iberian Peninsula (Western Mediterranean). Geomorphology 104, 4-11.

Fletcher, W.J., Boski, T., Moura, D., 2007. Palynological evidence for environmental and climatic change in the lower Guadiana valley, Portugal, during the last 13000 years. The Holocene 17-1, 481-494

Ginés, J., Fornós, J.J., Ginés, A., 2005. Els espeleotemes freátics del Quaternari de Mallorca: aspectes morfológics, mineralógics i cristal-Iográfics. In: Sanjaume, E.
Vicenc M. Rosselló Universitat de Valencia, pp. 151-165.

Gómez, M., Álvarez, E., Carretero, J.C., Pérez, B., Rodríguez, I., Serrano, •., Sotillo, M.G., 2002. Aceanographic and atmospheric analysis of the 10-16 November 2001 Storm in the western Mediterranean. Mediterranean storms. In Proceedings of the 4th EGS Plinius Conference Mallorca, Spain pp. 15-19.

Goy, J.L., Zazo, C., 1989. The role of neotectonics in the morphologic distribution of the Quaternary marine and continental deposits of the Elche Basin, southeast Spain. Tectonophysics 163, 219-225.

Goy, J.L, Zazo, C, Somoza, L, Dabrio, C. J., Bardaji, T., 1989. Litoral Bēticas Orientales. In: Zazo, C., Dabrio, C.J., Goy, J.L (Eds.), Libro Guia Excursión B, 1: Litoral Mediterráneo, II Reunión Cuaternario lbérico, Madrid, 99 pp.

Goy, J.L., Zazo, C., Cuerda, J., 1997. Evolución de las áreas margino-litorales de la Costa de Mallorca (I. Baleares) durante el último y Presente Interglacial. Nivel del mar Holoceno y Clima. Boletin Geológico y Minero 108, 127-135.

Goy, J.L., Zazo, C., Dabrio, C.J., 2003. A beach-ridge progradation complex reflecting periodical sea-level and climate variability during the Holocene (Gulf of Almeria, Western Mediterranean). Geomorphology 50, 251-268.

Goy, J.L., Hillaire-Marcel, C.1., Zazo, C., Ghaleb, B., Dabrio, C.J., González-Delgado, J.A. Bardaji, T., Civis, J., Preda, M., Yébenes, A., Forte, A.M., 2006. Further evidence for a relatively high sea level during the penultimate interglacial: open system $U$ series ages from La Marina (Alicante, East Spain). Geodinamica Acta 19/6, 409-426.

Hearty, P.J., Kindler, P., 1995. Sea-level highstand chronology from stable carbonate platforms (Bermuda and the Bahamas).Journalof Coastal Research 11 (3),675-689.

Hearty, P.J., Hollin, J.T., Dumas, B., 1987, Geochronology of Pleistocene littoral deposits on the Alicante and Almeria coasts of Spain. Trabajos sobre NeógenoCuaternario 10, 95-107.

Hearty, P.J., Hollin.J.T., Neumann, A.C. 'Leary, M.J., McCulloch, M., 2007. Global sealevel fluctuations during the last interglaciation (MIS 5e). Quaternary International 26, 2090-2112.

Hearty, P.J., 1986. An inventory of Last Interglacial (sl.) age deposits from the Mediterranean basin: a study in isoleucine epimerization and U/Ihe dating Zeitschrift für Geomorphologie Supplement Band 62, 51-69.

Hearty, P.J., 1987. New data on the Pleistocene of Mallorca. Quaternary Science Reviews 6. 245-257.

Hillaire-Marcel, C., Carro, e., Causse, C., Coy, J.-L, Zazo, C., 1986. The Stroinbus bubonius-bearing marine terraces in southeastern Spain. Geology 14, 613-616.

Hillaire-Marcel, Cl., Gariépy, Cl., Ghaleb, B., Goy, J.L., Zazo, C., Cuerda, J., 1996. $\mathrm{U}$-series measurements in Tyrrhenian deposits from Mallorca. Further evidente for two Last Interglacial high sea-levels in the Balearic Islands. Quaternary Science Reviews 15, 53-62.

Kaufman, A., Broecker, W.S., Ku, T.L., Thurber, D.L, 1971. The status of U/The methods of mollusc dating. Geochemica Cosmochemica Acta 35, 1155-1183.

Marcos, M., Tsimplis, M.N., Shaw, G.P., 2009. Sea level extremes in southern Europe. Journal of Geophysical Research 114, C01007.

McManus, J.F., Oppo, W.D., Cullen, J.L., 1999. A 0.5-million-year record of millennialscale climate variability in the North Atlantic. Science 283, 971-974

Miller, R.L., Ziegler, J.M., 1968. A model relating dynamics and sediment pattern in equilibrium in the region of shoaling waves, breaker zone, and foreshore. Journal Geology 66, 417-441.

Muhs, D.R. Simmons, KR, Steinke, B., 2002. Timing and warmth of the Last Interglacial period: new U-series evidence from Hawaii and Bermuda and a new fossil compilation for North America. Quaternary Science Reviews 21, $1355-1383$.

Müller, C, Klotz, S., Geyh, M.A., Pross, J., Bond, C.C., 2005. Cyclic climate fluctuations during the Last Interglacial in central Europe. Ceology 33 (6), 449-452

Mylroie, J.E., 2007. Late Quaternary sea level position: evidence from Bahamian carbonate deposition and dissolution cycles. Quaternary International 183. $61-75$.

Neumann, A.C., Hearty, P.J., 1996. Rapid sea-level changes at the close of the Last Interglacial (substage 5e) recorded in the Bahamian island geology. Geology 24 (9), 775-778.

-'Leary, M.J., Hearty, P.J., McCulloch, M.T., 2008. Geomorphic evidence of major sealevel fluctuations during marine isotope substage-5e, Cape Cuvier, Western Australia. Geomorphology 102, 595-602.

Plaziat, J.C., Reyss, J.L., Choukri, A., Orsag-Sperber, F., Baltzer, F., Purser, B.H., 1998. Mise en évidence, sur la côte récif ale d'Egypte, d'une régression interrompant brièvement le plus haut niveau du Dernier Interglaciaire: un nouvel indice de variations glacioeustatiques à haute fréquence au Pléistocène? Bulletin de la Société Géologique de France 169 (1) 115-125.

Rodriguez-Ramirez, A., Cáceres, L.M., Rodriguez Vidal, J., Cantano, M., 2000. Relación entre clima y génesis de crestas/surcos de playa en los últimos cuarenta años (Huelva, Golfo de Cádiz). Revista Cuaternario y Geomorfologia 14 (3-4), 109-113.

Roep, T.B., Dabrio, C.J., Fortuin, A.R, Polo, M.D., 1998. Late highstand patterns of shifing and stepping coastal barriers and washover-fans (Late-Messinian, Sorbas Basin, SE Spain). Sedimentary Ceology 116, 27-56.

Rohling, E.J., Grant, K, Hembelen, C, Siddall, M., Hoocakker, B.AA, Bolshaw, M. Kucera, M., 2008. High rates of sea-level rise during the Last Interglacial period. Nature Geoscience 1, 38-42

Schellmann, G., Radtke, U., 2004. A revised morpho- and chronostratigraphy of the Late and Middle Pleistocene coral reef terraces on southern Barbados (West Indies). Earth-Science Reviews 6A, 157-187. 
Schellmann, G., Radtke, U., Potter, E.-K., Esat, T.M., McCulloch, M.T.,2004. Comparison of ESR and TIMS U/The dating of marine isotope stage (MIS) 5e, 5c, and 5a coral from Barbados-implications for palaeo sea-level changes in the Caribbean. Quaternary International 120, 41-50.

Shackleton, N.J., Chapman, M., Sánchez-Goñi, M.F., Pailler, D., Lancelot, Y., 2002 The classic marine isotope substage 5 e. Quaternary Research 58, 14-16.

Somoza, L., Bardají, T., Dabrio, C.J., Goy, J.L., Zazo, C., 1986-87. Análisis de las secuencias de islas barrera pleistocénicas en relación con variaciones del nivel del mar. Lazuna de La Mata (Alicante). Acta Geolgica Hispanica 21-22, 151-157.

Stein, M., Wasserburg, G.J., Chen, J.H., Zhu, Z.R, Bloom, A., Chappell, J., 1993. TIMS U-series dating and stable isotopes of the Last Interglacial event in Papua New Guinea. Geochimica et Cosmochimica Acta 57, 2541-2554.

Szabo, J., Rosholt, N., 1969. Uranium-series dating of Pleistocene molluscan shells from southern California - An open system model. Journal of Geophysical Research 74, 3253-3260.

Szabo, B.J., Ludwig, K.R, Muhs, D.R, Simmons, K.R, 1994. Thorium-230 ages of corals and duration of the Last Interglacial sea-level high stand on oahu, Hawaii. Science 266, 93-96.

Tuccimei, P., Ginés, J., Delitala, M.C., Ginés, A., Gràcia, F., Fornós, J.J., Taddeucci, A. 2006. High precision U-series data from phreatic overgrowths on speleothems. Zeitschrift für Geomorphology 50 (1), 1-21.

White, B., Curran, H.A.,Wilson, M.A., 1998. Bahamiancoral reefs yield evidence of a brief sea-level lowstand during the Last Interglacial. Carbonates \& Evaporites 13, 10-22.
Wright, P., 1994. Paleosols in shallow marine carbonate sequences. Earth Science Reviews 35, 367-395.

Zazo, C., Silva, P.G., Goy, J.L., Hillaire-Marcel, C., Ghaleb, B., Lario, J., Bardaji, T., González, J.A., 1999. Coastal uplift in continental collision plate boundaries: data from the Last Interglacial marine terraces of the Gibraltar Strait area (south Spain). Tectonophysics 301, 95-109.

Zazo, C., Goy, J.L., Hillaire-Marcel, C., Gillot, P.Y., Soler, V., Gonzâlez-Delgado, J.A. Dabrio, C.J., Ghaleb, B., 2002. Raised marine sequences of Lanzarote and Fuerteventura revisited - a reappraisal of relative sea-level changes and vertica movements in the eastern Canary Islands during the Quaternary. Quaternary Science Reviews 21, 2019-2046.

Zazo, C., Goy, J.L., Dabrio, C.J., Barda jí, T., Hillaire-Marcel, C., Ghaleb, B., González Delgado, J.A., Soler, V., 2003. Pleistocene raised marine terraces of the Spanish Mediterranean and Atlantic coasts: records of coastal uplift, sea-level highstands and climate changes. Marine Geology 194, 103-133.

Zazo, C., Dabrio, C.J., Goy, J.L., Lario, J., Cabero, A., Silva, P.G., Bardaji, T., Mercier, N., Bor ja, F., Roquero, E., 2008. The coastal archives of the last $15 \mathrm{ka}$ in the AtlanticMediterranean Spanish linkage area: sea level and climate changes. Quaternary International 181, 72-87.

Zhu, Z.R, Wyrwoll, K.-H., Collins, LB., Chen, J.H., Wasserburg, G.J., Eisenhauer, A. 1993. High precision U-series dating of Last Interglacial events by mass-spectrometry: Houtman Abrolhos Islands, Western Australia. Earth Planetary Science Letters 118, 281-293. 